\title{
Spatial Variability of Physical Soil Quality Index of an Agricultural Field
}

\author{
Sheikh M. Fazle Rabbi, Bina R. Roy, M. Masum Miah, \\ M. Sadiqul Amin, and Tania Khandakar
}

\author{
Soil Science Discipline, Khulna University, Khulna 9208, Bangladesh \\ Correspondence should be addressed to Sheikh M. Fazle Rabbi; fazlerabbi76@yahoo.com
}

Received 31 December 2013; Revised 5 April 2014; Accepted 7 April 2014; Published 4 May 2014

Academic Editor: Teodoro M. Miano

Copyright (c) 2014 Sheikh M. Fazle Rabbi et al. This is an open access article distributed under the Creative Commons Attribution License, which permits unrestricted use, distribution, and reproduction in any medium, provided the original work is properly cited.

\begin{abstract}
A field investigation was carried out to evaluate the spatial variability of physical indicators of soil quality of an agricultural field and to construct a physical soil quality index $\left(\mathrm{SQI}_{\mathrm{p}}\right)$ map. Surface soil samples were collected using $10 \mathrm{~m} \times 10 \mathrm{~m}$ grid from an Inceptisol on Ganges Tidal Floodplain of Bangladesh. Five physical soil quality indicators, soil texture, bulk density, porosity, saturated hydraulic conductivity $\left(K_{S}\right)$, and aggregate stability (measured as mean weight diameter, MWD) were determined. The spatial structures of sand, clay, and $K_{S}$ were moderate but the structure was strong for silt, bulk density, porosity, and MWD. Each of the physical soil quality indicators was transformed into 0 and 1 using threshold criteria which are required for crop production. The transformed indicators were the combined into SQI ${ }_{P}$. The kriged SQI $I_{P}$ map showed that the agricultural field studied could be divided into two parts having "good physical quality" and "poor physical soil quality."
\end{abstract}

\section{Introduction}

The term and concept of soil quality evoke various responses, depending on our scientific and social backgrounds. Soil quality is an integration of soil processes and provides a measure of change in soil condition as related to factors such as land use, climate patterns, cropping sequences, and farming systems [1]. Presently, soil quality has been defined by some scientist as "capacity of soil to function" [2]. Soil quality can be assessed by selecting different indicators upon which the functions of soil depend [2]. Doran and Parkin [2] have developed a list of basic soil properties or indicators for screening soil quality and health. USDA Staff [3] categorizes the soil quality indicators into four general groups: visual, physical, chemical, and biological. A minimum data set (MDS) was also proposed to assess soil quality. Soil MDS of different soil properties can be chosen as an indicator of soil quality and can also be transformed into overall indicator of soil quality for monitoring [4]. The application of these properties at regional and local scales requires the development of efficient sampling and soil quality management strategies. This in turn requires information on the spatial variability of properties across different types of soils and land uses. Like other soil properties, soil quality can vary spatially [5]. Several studies have documented that soil properties vary across farm fields, causing spatial variability in crop yields [6]. Precision farming or site-specific management aims at managing soil spatial variability by applying inputs in accordance with the site-specific requirements of a specific soil and crop [7]. Such practices require quantification of soil spatial variability across the field. Geostatistics provides procedures to assess spatial dependence [8].

The degree of spatial variability for each variable can be determined by geostatistical methods using semivariogram model [9]. Classical statistics requires the validity of some basic hypotheses, such as the independence between observations, due to the randomness of variations from one place to another. In addition, geostatistics, based on the theory of regionalized variables, enables the interpretation of results based on the structure of spatial dependence within the sample space [10].

Among the soil quality indicators the physical soil quality indicators influence both chemical and biological quality of soil. The soil physical properties are associated with nutrient 
availability, solute and pollutant movement, microbial activity, and soil organic matter stabilization [11]. Spatial variability of soil physical properties within or among agricultural fields is inherent in nature due to geologic and pedologic soil forming factors, but some of the variability may be induced by tillage and other management practices. These factors interact with each other across spatial and temporal scales and are further modified locally by erosion and deposition processes [12]. Among the various soil physical properties, saturated hydraulic conductivity $\left(K_{S}\right)$ and related measures are reported to have the highest statistical variability [13]. Bouma [14] stressed the need for more studies on field variability of $K_{S}$ and soil water retention curves. Stockton and Warrick [15] indicated that variability in $K_{S}$ is both a function of soil depth and position in the landscape, as well as experimental errors in measuring $K_{S}$. The spatial variability and scaling of $K_{S}$ have been studied by several authors using geostatistical techniques. Sobieraj et al. [16] used classical and geostatistical techniques to the study spatial variability of sand, silt, and clay contents, available water content, and water stored at $-33 \mathrm{kPa}$. Iqbal et al. [12] studied the spatial variability of percent sand, silt and clay, bulk density, organic matter, and available water holding capacity of soil. However, integrating measured soil physical quality indicators into a single physical soil quality index is quite challenging considering the scale and units of measurements of soil quality indicators. The transformation of measured physical soil quality indicators into unitless binary digits depending on whether the indicators are capable to function adequately in a particular ecosystem could be a good approach to integrate measured indicators in a single soil quality index [17]. However, the single soil quality index on the basis of whether any of the soil quality indicators meet certain soil quality threshold does not include how effectively the soil is performing its function. Therefore, instead of single soil quality index, several soil quality indices of a particular soil on the basis of the number of soil quality indicators that meet the soil quality threshold would be a better approach to evaluate soil quality.

The objectives of the research work were to (i) evaluate the spatial variability of physical indicators of soil quality of an agricultural field and (ii) defining and mapping of soil quality index.

\section{Materials and Methods}

2.1. Sample Collection and Analyses. The study was conducted on an agricultural field of approximately $7000 \mathrm{~m}^{2}$ at Khulna, Bangladesh. The georeference of the study area is shown in Figure 1. The mean annual temperature and rainfall are $26^{\circ} \mathrm{C}$ and $1693 \mathrm{~mm}$, respectively. The climate is characterized by a tropical monsoon climate [18]. According to the USDA soil taxonomy the soils are of Inceptisol order and located on the Ganges Tidal Floodplain of Bangladesh [19]. Soil samples were collected by establishing a sampling grid (Figure 1). The grid had four transects, parallel to $x$-axis, with a spacing of $10 \mathrm{~m}$. It contained 10 sample points with spacing of $10 \mathrm{~m}$. A total of 40 surface soil $(0-5 \mathrm{~cm})$ samples were collected from $10 \mathrm{~m} \times 10 \mathrm{~m}$ sample points for determination of physical
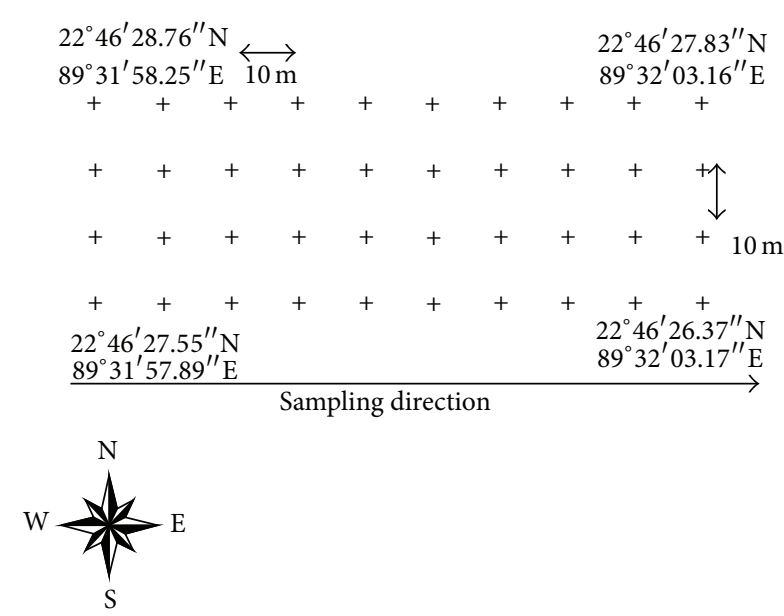

FIGURE 1: Soil sampling grid for selected physical soil quality indicators of an agricultural field of Ganges Tidal Floodplain soil (classified as Inceptisols order of US Soil Taxonomy), Bangladesh.

indicators of soil quality. The indicators were selected as proposed by USDA Staff [3] and Karlen and Stott [20]. The indicators measured in the present investigation were soil texture, bulk density, porosity, aggregate stability, and $K_{S}$.

Undisturbed soil cores ( $5 \mathrm{~cm}$ in diameter) were collected for bulk density, porosity, aggregate stability, and $K_{S}$ determination in the laboratory. The soil core samples were collected in 6 replicates from each location. Particle size analysis of the soils was done by hydrometer methods [21]. Bulk density was determined by the core sampling method as described by Blake and Hartge [22]. Particle density of soil was determined by the pycnometer method [22]. Total porosity of soil was calculated from the data of particle density and bulk density [23]. The determination of aggregate stability by wet sieving involves the estimation of the amount of intact aggregates against the forces of water entry into aggregates, such as forces related to water entry in soil aggregates. It is generally considered that retention of large aggregates against forces of water entry is indicative of good aggregate stability [24]. Therefore, to evaluate the aggregate stability of the soil, mean weight diameter (MWD) was determined using wet sieving. The size ranges of aggregates used to calculate the MWD were $1.0-2.0 \mathrm{~mm}, 0.5-1.0 \mathrm{~mm}, 0.25-0.5 \mathrm{~mm}$, and $0.125-0.25 \mathrm{~mm}$. The MWD of the aggregates was calculated as

$$
\mathrm{MWD}=\sum_{i=1}^{n} X_{i} W_{i}
$$

where $n=$ number of size fractions, $X_{i}=$ the mean diameter of any particular size range of aggregates separated by sieving, and $W_{i}=$ the weight of aggregates in that size range as a fraction of the total dry weight of the sample analyzed [24]. Saturated hydraulic conductivity $\left(K_{S}\right)$ of the soil was determined in the laboratory by measuring the flux of water through the undisturbed soil core under a constant water head maintained at the top of the soil core [25]. 
TABLE 1: Threshold ranges of physical soil quality indicators for crop production.

\begin{tabular}{|c|c|c|c|}
\hline Physical soil quality indicator & Threshold range & Comment & References \\
\hline Clay, \% & $\leq 40$ & $>40 \%$ impede soil water movement and redistribution & USDA staff [26] \\
\hline Bulk density, $\mathrm{g} \mathrm{cm}^{-3}$ & $0.9-1.2$ & $\begin{array}{l}\text { In fine textured soils bulk density }<0.9 \mathrm{~g} \mathrm{~cm}^{-3} \text { may } \\
\text { provide insufficient soil-root contact, water retention, } \\
\text { and plant anchoring whereas bulk density }>1.2 \mathrm{~g} \mathrm{~cm}^{-3} \\
\text { may impede root elongation and reduce soil aeration }\end{array}$ & Reynolds et al. [27] \\
\hline Porosity, \% & $\geq 50-65$ & $\begin{array}{l}10 \% \text { (by volume) air filled porosity is considered } \\
\text { limiting for plant growth. }>50 \% \text { of total porosity is } \\
\text { considered quite adequate to provide } 10 \% \text { air filled } \\
\text { porosity in silty clay and clay soils }\end{array}$ & $\begin{array}{c}\text { Hall et al. [28] } \\
\text { Joshua and Rahman [29] }\end{array}$ \\
\hline$K_{S}^{\ddagger}, \mathrm{cm} \mathrm{day}^{-1}$ & $\geq 8.64-43.2$ & $\begin{array}{l}\text { In fine textured soil, } K_{S}<8.64 \mathrm{~cm}^{-1} \text { day }^{-1} \text { substantially } \\
\text { reduced crop production by inadequate aeration in root } \\
\text { zone, whereas } K_{S} 43.2 \mathrm{~cm} \mathrm{day}^{-1} \text { may consider ideal for } \\
\text { rapid infiltration and redistribution of crop available } \\
\text { water }\end{array}$ & $\begin{array}{l}\text { Reynolds et al. [27] } \\
\text { McQueen and Shepherd [30] }\end{array}$ \\
\hline $\mathrm{MWD}^{\#}, \mathrm{~mm}$ & $\geq 1-3$ & $\begin{array}{l}\text { Soil aggregates with }>1 \mathrm{~mm} \text { MWD is considered } \\
\text { moderately water stable }\end{array}$ & Rabbi et al. [31] \\
\hline
\end{tabular}

${ }^{\text {} S}$ Saturated hydraulic conductivity; ${ }^{\#}$ mean weight diameter.

To construct a physical soil quality index $\left(\mathrm{SQI}_{\mathrm{P}}\right)$ we transformed the measured physical soil quality parameters into 0 and 1 by comparing individual physical soil quality indicator with the threshold range from literature which represents the best quality for crop production [17]. If any indicator failed to meet the specific threshold range then the data was coded as 0 and otherwise 1 . The criteria that are used for indicator transformation are presented in Table 1. As hydrologic properties are strongly affected by the clay percentage of soil, the clay percentage instead of sand and silt was used to construct SQI . During selecting the threshold for soil quality indicators crops other than lowland rice (Oryza sativa) were considered. After transforming the physical soil quality indicators, we combined the transformed indicators into a single $\mathrm{SQI}_{\mathrm{P}}$ value by evaluating how many measured physical soil quality parameter satisfied the threshold ranges (Table 1) of good soil quality. We set three combination scenarios which were termed as $\mathrm{SQI}_{\mathrm{P}}$ (2 of 5), $\mathrm{SQI}_{\mathrm{P}}$ (3 of 5 ), and $\mathrm{SQI}_{\mathrm{P}}$ (4 of 5). If 2 measured indicators satisfied the threshold range of good soil quality then the $\mathrm{SQI}_{\mathrm{P}}$ (2 of 5 ) would be 1 and otherwise 0 . Similar combinations were carried out for SQI $(3$ of 5) and SQI $(4$ of 5). An example of indicator transformation used in the current research is presented in Table 2.

2.3. Statistical Methods. Data was statistically analyzed in three phases: (1) data were described using the classical statistics (mean, mode, median, standard deviation, coefficient of variation, skewness, and kurtosis); (2) frequency distribution was examined and the test for normality was conducted. The Ryan-Joiner test [33] revealed that all measured variables were normally distributed except the hydraulic conductivity. Since the $R^{2}$ of normal probability plot for the hydraulic conductivity was $0.85(P<0.01)$ we assumed that it would not strongly affect the fitting of semivariogram models; (3) the spatial structure of different physical soil quality parameters were determined. The statistical analyses of data were carried out by MINITAB (release 13.20) and we created contour maps of each variable through ordinary kriging using their respective semivariogram models by using SURFER 12.0 software.

The degree of spatial dependence for each variable was determined with geostatistical methods using semivariogram analysis and kriging [9]. The semivariogram $\gamma(h)$ is by definition [34]

$$
\gamma(h)=\frac{1}{2 N(h)} \sum_{i=1}^{N(h)}\left[z_{(i+h)}-z_{i}\right]^{2},
$$

where $N(h)$ is the number of experimental pairs $\left[z_{(i+h)}, z_{i}\right]$ of data separated by a vector $h$. A semivariogram consists of three basic parameters which describe the spatial structure as $\gamma(h)=C_{r}+C, h \geq r \cdot C_{0}$ represents the nugget effect, which is local variation occurring at scales smaller than the sampling interval, such as sampling error; $C_{0}+$ $C$ is the sill (total variance); and $r$ is the range, at which semivariogram levels off (beyond that distance the variables are not spatially correlated). Data were linearly detrended to create semivariogram. The presence of anisotropy was detected by changing the lag direction and detecting the changes in length scale in semivariogram using Surfer 12.0 software. After setting initial anisotropy parameters, the semivariogram models were fitted by least square method with 50 iterations. The semivariogram models of the soil quality indicators (i.e., sand, silt, clay, bulk density, porosity, MWD, and $K_{S}$ ) and $S \mathrm{SI}_{\mathrm{P}}$ were produced. Since the exact form of semivariogram model was never known the given model selected and used was only an approximation of its function [34]. The semivariogram models were then used to undertake ordinary kriging to create contour map of soil quality indicators and SQI . The cross-validation of semivariogram models and kriging was undertaken by calculating gridding error (i.e., difference between interpolated and observed value of a data point) using spherical, exponential, 


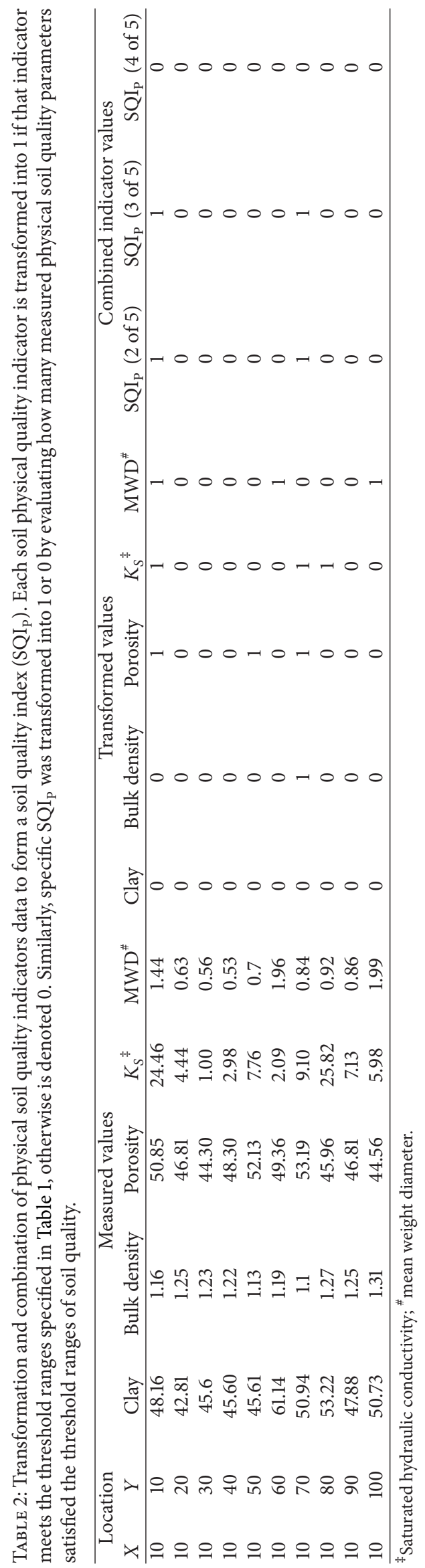


TABLE 3: Descriptive statistics for selected physical soil quality indicators of an agricultural field of Ganges Tidal Floodplain soil (classified as Inceptisols order of US Soil Taxonomy), Bangladesh, collected using $10 \mathrm{~m} \times 10 \mathrm{~m}$ grid sampling technique.

\begin{tabular}{|c|c|c|c|c|c|c|c|}
\hline Physical soil quality indicators & Minimum & Maximum & Mean & Median & Standard deviation & Skewness & Kurtosis \\
\hline Sand, $\%$ & 3.16 & 16.42 & 9.60 & 9.64 & 3.43 & -0.13 & -0.56 \\
\hline Silt, \% & 25.5 & 51.03 & 39.74 & 38.25 & 6.44 & 0.002 & -0.57 \\
\hline Clay, \% & 42.81 & 61.14 & 50.66 & 49.45 & 5.87 & 0.50 & -0.87 \\
\hline Bulk density, $\mathrm{g} \mathrm{cm}^{-3}$ & 0.99 & 1.34 & 1.22 & 1.24 & 0.09 & -0.72 & 0.06 \\
\hline Porosity, \% & 43.3 & 57.91 & 48.23 & 47.56 & 3.61 & 0.83 & 0.55 \\
\hline$K_{S}^{\ddagger}, \mathrm{cm} \mathrm{day}^{-1}$ & 1.00 & 41.9 & 11.78 & 7.16 & 12.11 & 1.30 & 0.69 \\
\hline $\mathrm{MWD}^{\#}, \mathrm{~mm}$ & 0.53 & 2.38 & 1.46 & 1.52 & 0.58 & -0.15 & -1.08 \\
\hline
\end{tabular}

${ }^{\ddagger}$ Saturated hydraulic conductivity; ${ }^{\#}$ mean weight diameter.

TABLE 4: Semivariogram model parameters of physical soil quality indicators of an agricultural field of Ganges Tidal Floodplain soil (classified as Inceptisols order of US Soil Taxonomy), Bangladesh, collected using $10 \mathrm{~m} \times 10 \mathrm{~m}$ grid sampling technique.

\begin{tabular}{|c|c|c|c|c|c|c|}
\hline Physical Soil quality indicators & Model & Nugget & Sill & $\%$ Nugget $^{*}$ & Spatial $^{* *}$ class & Range \\
\hline Sand, \% & Spherical & 3.1 & 11.2 & 27.7 & Moderate & 25 \\
\hline Silt, \% & Spherical & 1.1 & 32.1 & 3.4 & Strong & 22 \\
\hline Clay, \% & Spherical & 11.8 & 27.8 & 42.4 & Moderate & 25 \\
\hline Bulk density, $\mathrm{g} \mathrm{cm}^{-3}$ & Spherical & 0.0005 & 0.01 & 5.0 & Strong & 21 \\
\hline Porosity, \% & Spherical & 2.3 & 12.3 & 18.7 & Strong & 25 \\
\hline$K_{S}^{\ddagger}, \mathrm{cm} \mathrm{day}^{-1}$ & Spherical & 90.5 & 150.4 & 60.2 & Moderate & 30 \\
\hline $\mathrm{MWD}^{\#}, \mathrm{~mm}$ & Spherical & 0.03 & 0.3 & 10.0 & Strong & 32 \\
\hline
\end{tabular}

$\%$ Nugget $=$ (nugget semivariance/total semivariance $) \times 100$.

${ }^{* *}$ Strong $=\%$ Nugget $<25 \%$; Moderate $=\%$ Nugget $25-75 \%$; Weak or Random $=\%$ Nugget $>75 \%$ Cambardella et al. [32] $)$.

${ }^{\ddagger}$ Saturated hydraulic conductivity; ${ }^{*}$ mean weight diameter.

and linear semivariogram model [35]. The gridding errors were calculated by successive removal of data points and interpolation of the removed data point using the remaining data. After interpolation of all data points, root mean square error (RMSE) was calculated as follows: RMSE = $(100 / m) \sqrt{\sum(i-o)^{2} / n}$, where $m$ is the mean of observed values, $i$ is the interpolated value, $o$ is the observed values, and $n$ is the number of observations [36]. The RMSE would be 0 in case of $100 \%$ fit. The spherical model had lower RMSE value compared to linear and exponential models and thus selected as the acceptable model.

\section{Results and Discussion}

3.1. Variation in Physical Soil Quality Indicators across the Agricultural Field. The percentages of sand, silt, and clay of soil samples studied indicated that the soils were fine in texture (Table 3) and textural class of the soil samples varied between silty clay and clay. The study area was located in the southeastern coastal belt of Bangladesh. This area has numerous tidal river connected to the Bay of Bengal. The soils of this area are formed on tidal clay sediments and flooding occurrence during the monsoon each year are the reasons for containing high percentage of silt and clay [37]. The reported bulk density in the current study was lower than the bulk density of $1.47 \mathrm{~g} \mathrm{~cm}^{-3}$ at which root development becomes restricted [38]. The mean $K_{S}$ was $12 \mathrm{~cm} \mathrm{day}^{-1}$ which suggests that the saturated hydraulic conductivity of soil was moderately high [26]. Soil aggregates were not strongly water stable which was indicated by mean MWD value (i.e., $1.46 \mathrm{~mm}$ ) of the area studied. Rabbi et al. [31] compared measured MWD with field observed grade of soil structure and concluded that the soils with MWD between 1 and $3 \mathrm{~mm}$ could be classified as moderately water stable. Therefore, on an average, the soils of the agricultural field studied had favorable physical quality for plant growth.

3.2. Spatial Structure of Physical Soil Quality Indicators. The range of MWD (33) was the highest compared of all other soil quality parameters (Table 4 and Figure 2). The ranges of the measured physical soil quality parameters varied between 21 and $32 \mathrm{~m}$ which reflects high variability in soil quality. Due to seasonal occurrence of floods in the study area, the silt, clay and clay minerals, and organic matter content of the flood sediment usually vary considerably [37]. The high variability in properties of flood sediments may be responsible for high spatial variability of soil quality indicators.

The spatial structure of the semivariogram models was defined by the classes of spatial dependence proposed by Cambardella et al. [32]. Very high nugget values tend to mask the degree of spatial structure [39]. Therefore, relative nugget effect (i.e., nugget semivariance as a percentage of total semivariance) has been used to classify the spatial dependence of soil properties [32]. The lower the relative nugget effect is, the stronger the spatial dependence is. Among the 

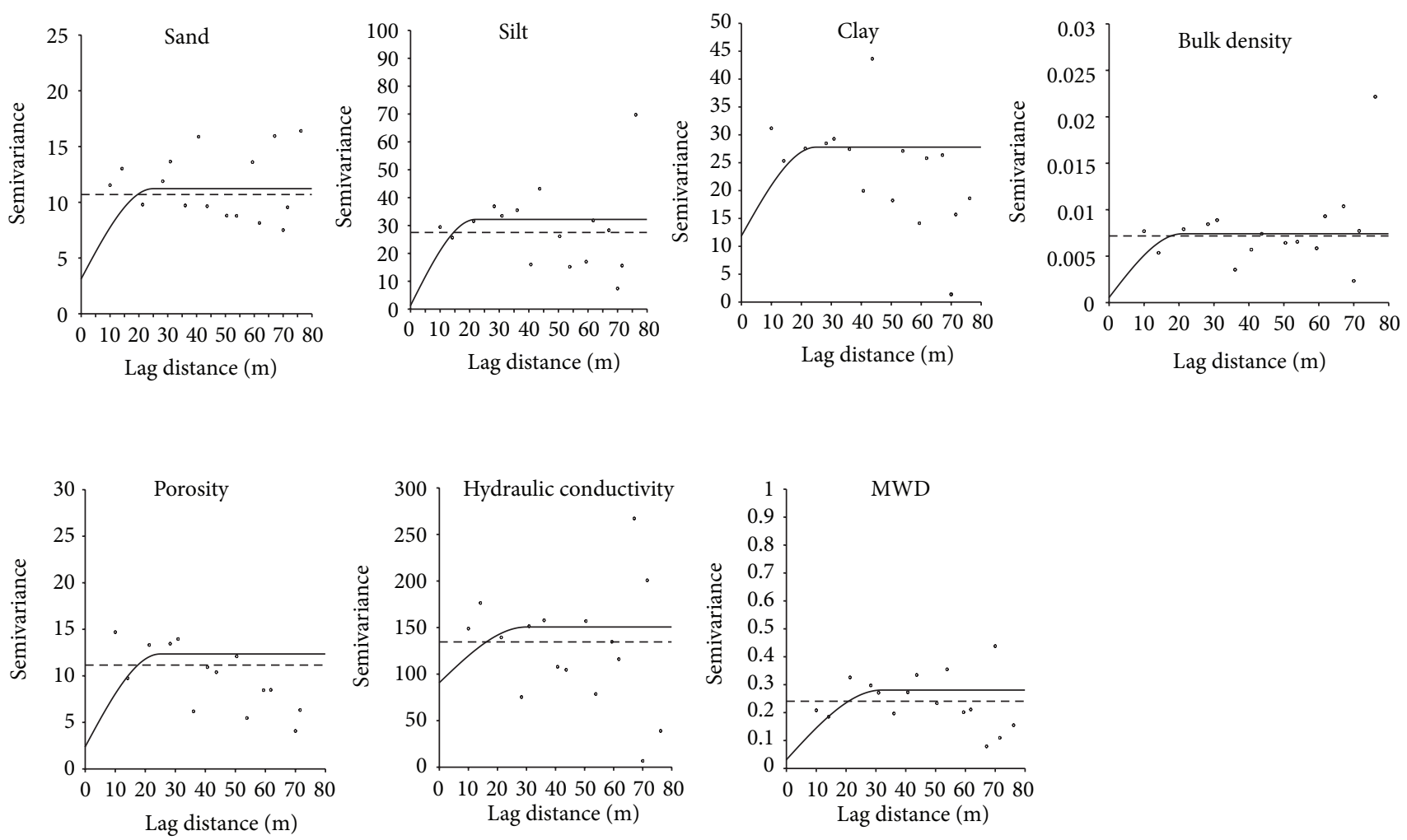

FIGURE 2: Experimental (symbol) and fitted (line) semivariograms of physical soil quality indicators ( $y$ axis of the semivariograms is at different scale).

measured variables sand, clay, and $K_{S}$ showed moderate spatial dependence while the silt, bulk density, porosity, and MWD showed strong spatial dependence (Table 4). Iqbal et al. [12] stated that the spatial structure of sand was strong but was moderate for clay. In our investigation spatial structure of sand and clay was moderate. Tsegaye and Hill [40] observed lower structural variability and range in bulk density while Iqbal et al. [12] reported high range and moderate spatial structure. The structural variability in bulk density was strong in the present investigation. Basaran et al. [41] observed a strong spatial dependence but Iqbal et al. [12] found a moderate spatial structure for $K_{S}$ which was also reported in this study. Shukla et al. [42] studied the spatial variability of MWD and found occurrence of spatial dependence. The present study also reported strong spatial dependence of MWD, which was well corroborated with the findings of Shukla et al. [42].

3.3. Kriged Contour Maps of Physical Soil Quality Indicators. Kriged contour maps of the measured variables showed that silt was higher at the western part than the eastern part of the field (Figure 3). The percentage of clay was lower at the western part than the eastern part of the field. As the percentage of silt was high, the bulk density of the western part of the field was much lower than the eastern part. The spatial variation of bulk density was also in good agreement with the spatial variation of porosity in the field. Although percentages of clay, bulk density, and porosity have a strong influence on $K_{S}$, the kriged contour maps of the current study showed a weak influence of clay, bulk density, and porosity on $K_{S}$. For example, western part of the study area had low percent clay and higher porosity but the $K_{S}$ of this part was low. The MWD was higher in the middle part of the field. The percentage of silt at the middle part of the field was low which might be a reason for higher MWD in this area. Rabbi et al. [31] reported that MWD of tidal floodplain soils decreases with the increase in silt content of the soil. The variation of various soil physical parameters revealed in the kriged contour maps implies the significance of the depositional activity of tidal river.

3.4. Spatial Structure of Physical Soil Quality Index (SQI $\left.{ }_{P}\right)$. The spatial analysis showed that the spatial dependence of (2 of 5), $\mathrm{SQI}_{\mathrm{P}}$ (3 of 5), and $\mathrm{SQI}_{\mathrm{P}}$ (4 of 5) was strong. The highest sill value was obtained for $\mathrm{SQI}_{\mathrm{p}}(2$ of 5 ) and lowest for $\mathrm{SQI}_{\mathrm{P}}$ (4 of 5) (Figure 4). The range values of $\mathrm{SQI}_{\mathrm{P}}$ varied from 25 to $46 \mathrm{~m}$. The highest range value was found in $\mathrm{SQI}_{\mathrm{P}}$ ( 4 of 5). The high range value of $\mathrm{SQI}_{\mathrm{P}}$ ( 4 of 5 ) indicated that under strict soil quality criteria combined soil quality was spatially related to longer lag distance. The kriged map of $\mathrm{SQI}_{\mathrm{P}}$ showed that soil quality across the field changes more rapidly in $\mathrm{SQI}_{\mathrm{P}}$ (2 of 5) than in the other two combinations and overall the probability of soil quality indicators exceeding the thresholds was 55\%. On the basis of the set physical soil quality criteria it was strongly revealed that south-western and south-eastern part of the kriged map of $\mathrm{SQI}_{\mathrm{P}}$ (3 of 5) had 


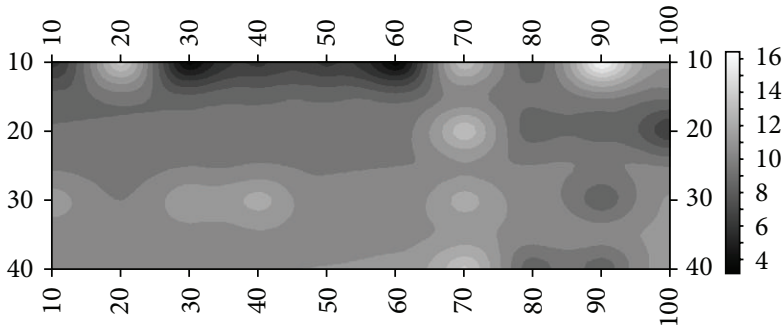

(a)

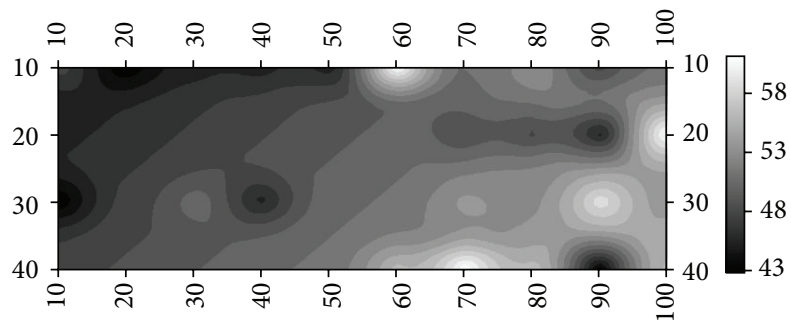

(c)

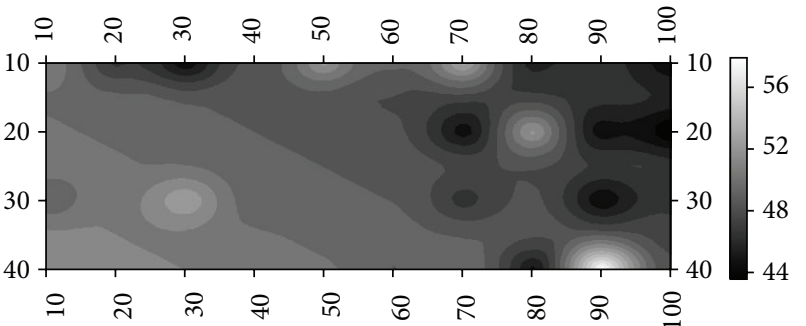

(e)

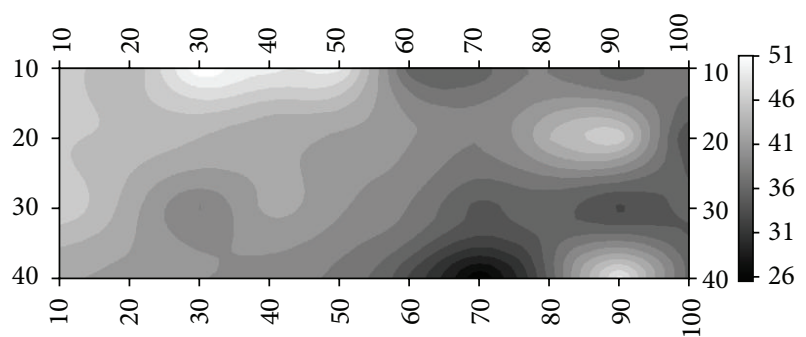

(b)

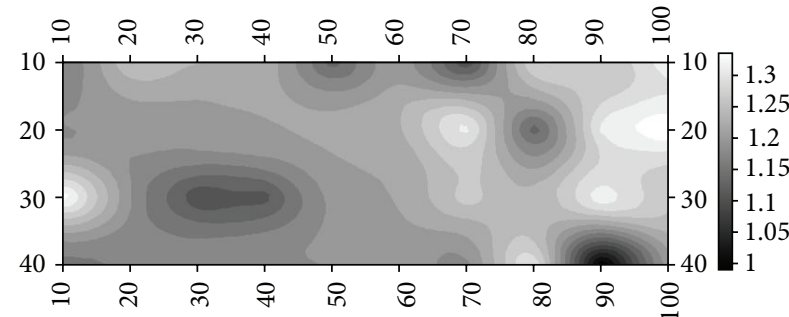

(d)

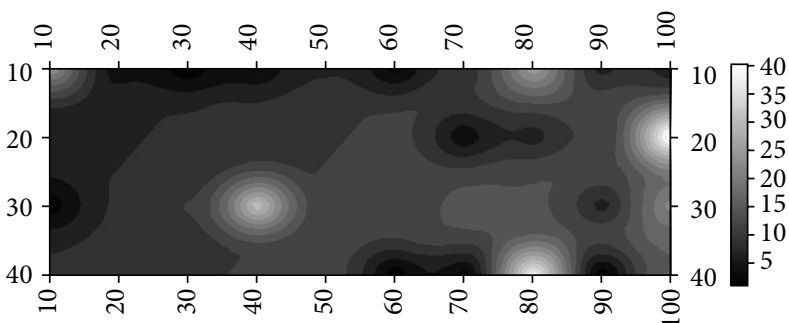

(f)
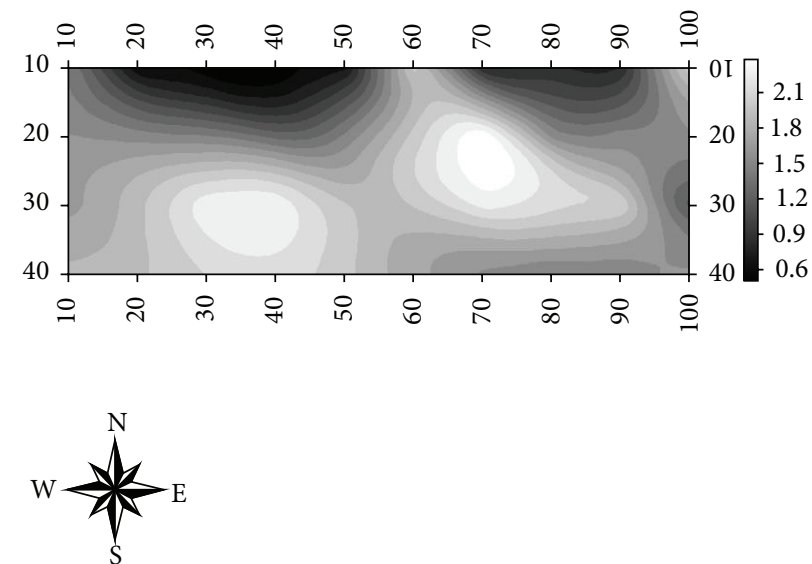

(g)

FIGURE 3: Kriged maps showing spatial variability of physical soil quality indicators (a) sand (\%), (b) silt (\%), (c) clay (\%), (d) bulk density (g $\left.\mathrm{cm}^{-3}\right)$, (e) porosity (\%), (f) $K_{S}\left(\mathrm{~cm} \mathrm{day}^{-1}\right)$, and $(\mathrm{g}) \mathrm{MWD}(\mathrm{mm})$ of Inceptisol in Ganges Tidal Floodplain of Bangladesh.

$90 \%$ probability of exceeding soil quality threshold ranges. Similar to $\mathrm{SQI}_{\mathrm{P}}$ (3 of 5) the $\mathrm{SQI}_{\mathrm{P}}$ (4 of 5) showed that 4 soil quality indicators at the south-western part had $95 \%$ chance of meeting threshold range and had only $<20 \%$ chance in the eastern part. Therefore, the field can be divided into two distinct parts having a "good physical soil quality" and a "poor physical soil quality" based on the probability values. As shown in Figure 5(c), south-western part was better in soil physical quality than that of the eastern part of the field.
Since the spatial variability of physical properties of soil has implications for water storage, nutrient management, and crop selection [12], the spatial variability of $\mathrm{SQI}_{\mathrm{P}}$ can be used to identify sites for better crop production.

\section{Conclusion}

The highest range of semivariogram models of the measured physical soil quality indicators was $\sim 30 \mathrm{~m}$, which reflects high 

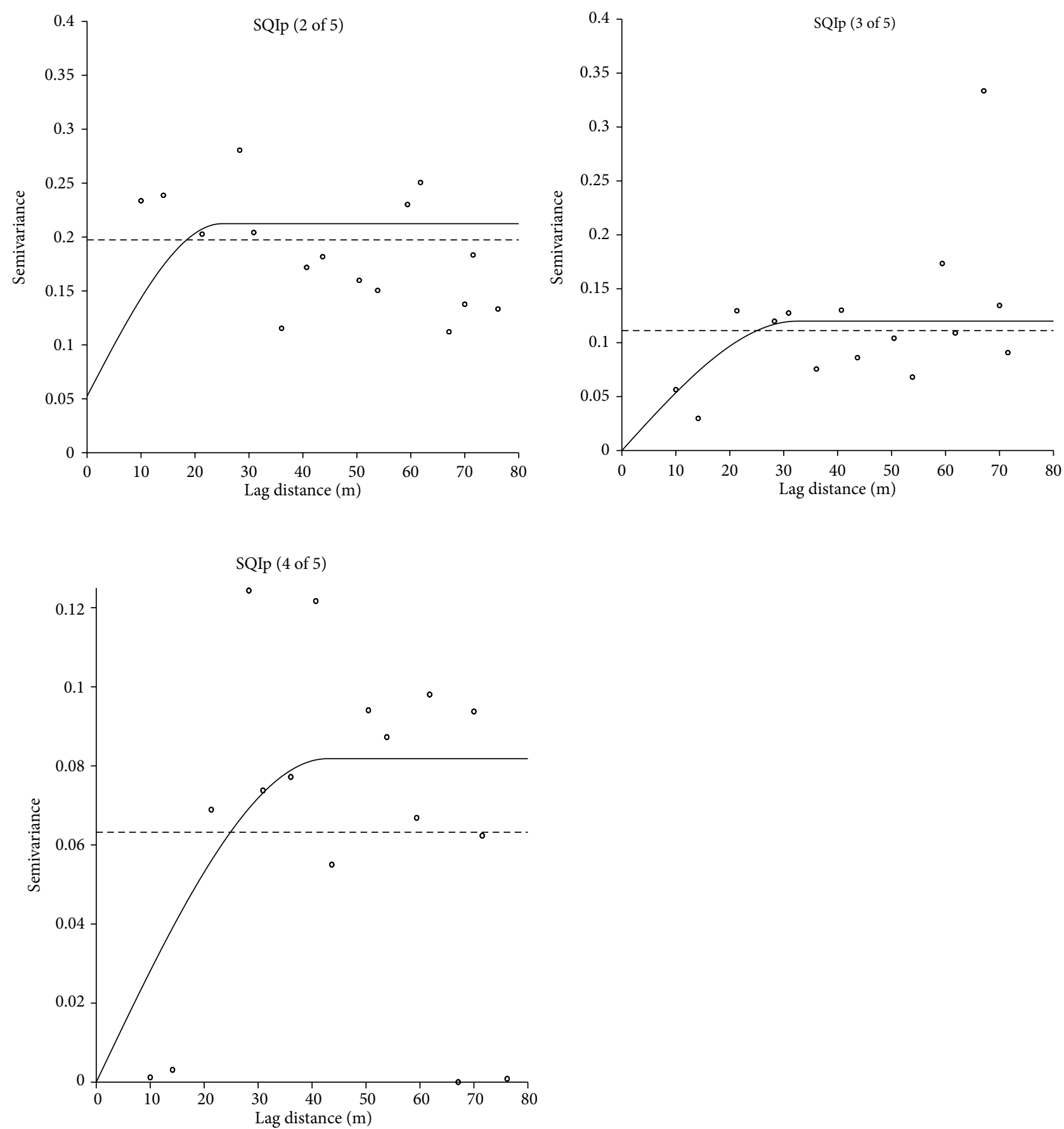

FIGURE 4: Experimental (symbol) and fitted (line) semivariograms of physical soil quality index ( $\mathrm{SQI}_{\mathrm{P}}$ ) ( $y$ axis of the semivariograms is at different scale).

spatial variability in soil quality. Since the study area had high occurrence of seasonal floods, the high variability in soil properties might be related to variability of properties of flood sediments. The measured physical soil quality indicators were transformed and combined into three physical soil quality indices, that is, $\mathrm{SQI}_{\mathrm{P}}$ (2 of 5), $\mathrm{SQI}_{\mathrm{P}}$ (3 of 5), and $\mathrm{SQI}_{\mathrm{P}}$ (4 of $5)$. On the basis of the set physical soil quality criteria it was strongly revealed that in case of SQI $\mathrm{P}_{\mathrm{P}}(2$ of 5) the entire field studied had overall $55 \%$ chance of meeting threshold range of at least 2 soil quality indicators. Under $\mathrm{SQI}_{\mathrm{P}}$ (3 of 5) scenario, the soil quality index map showed $90 \%$ chance of meeting threshold ranges of 3 soil quality indicators at south-western and south-eastern parts of the agricultural field studied, whereas south-western part had $>95 \%$ chance of meeting $\mathrm{SQI}_{\mathrm{P}}$ (4 of 5) criterion. Therefore, the soil quality indices obtained by transformation and combination of indicators, could be useful to evaluate the spatial variability of physical soil quality of an agricultural field. 


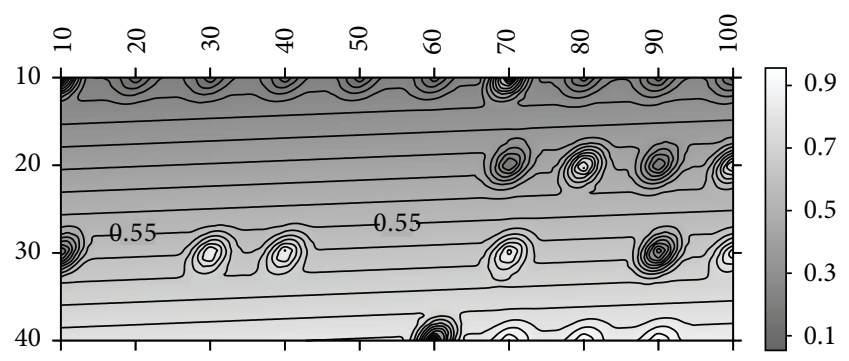

(a)

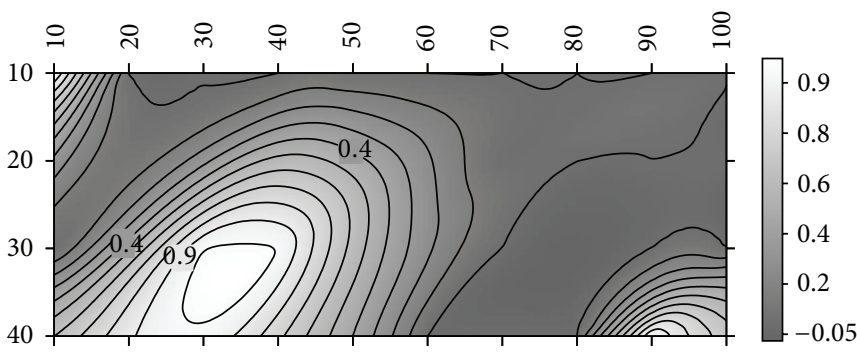

(b)
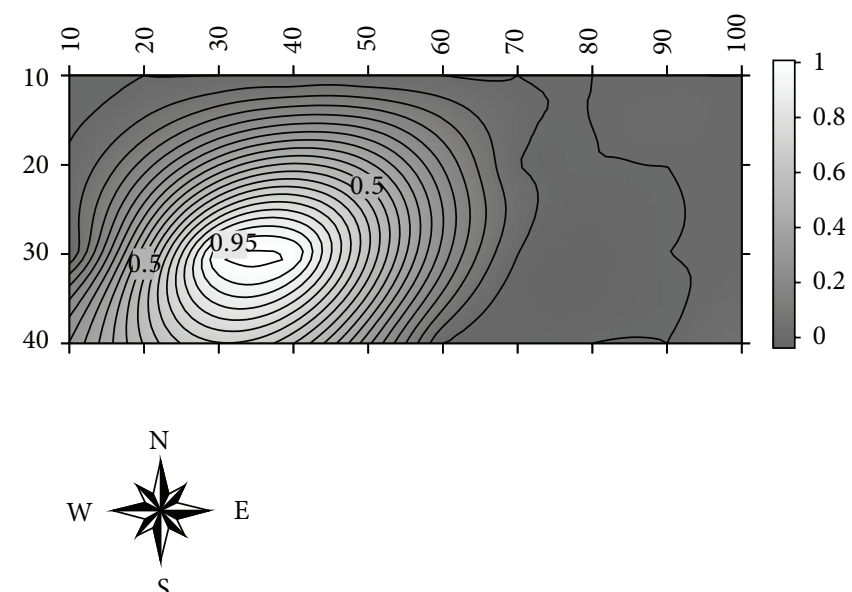

(c)

FIGURE 5: Kriged maps showing spatial variability of physical soil quality index ( $\mathrm{SQI}_{\mathrm{P}}$ ) (a) $\mathrm{SQI}_{\mathrm{p}}$ (2 of 5), (b) SQI $\mathrm{P}_{\mathrm{P}}$ (3 of 5), and (c) SQI $\mathrm{P}_{\mathrm{P}}$ (4 of 5). Gray scale showing 0 is poor and 1 is good soil physical quality.

\section{Conflict of Interests}

The authors declare that there is no conflict of interests regarding the publication of this paper.

\section{References}

[1] J. W. Doran, M. Sarrantonio, and M. A. Liebig, "Soil Health and Sustainability," Advances in Agronomy, vol. 56, pp. 1-54, 1996.

[2] J. W. Doran and T. B. Parkin, "Defining and assessing soil quality," in Defining Soil Quality for a Sustainable Environment, J. W. Doran, D. C. Coleman, D. F. Bezdicek, and B. A. Stewart, Eds., vol. 35 of SSSA Special Publication, pp. 3-2, ASA, CSSA, and SSSA, Madison, Wis, USA, 1994.

[3] USDA (United States Department of Agriculture) Staff, "Indicators for soil quality," Soil Quality Information Sheet, USDA-NRCS, Washington, DC, USA, 1996, http://soils.usda.gov/sqi/publications/files/sq_thr_2.pdf.

[4] C. A. Seybold, M. J. Mausbach, D. L. Karlen, and H. H. Rogers, "Quantification of soil quality," in Soil Processes and the Carbon Cycle, R. Lal, J. M. Kimble, R. F. Follett, and B. A. Stewart, Eds., pp. 387-404, CRC Press, Boca Raton, Fla, USA, 1998.

[5] D. J. Giltrap and A. E. Hewitt, "Spatial variability of soil quality indicators in New Zealand soils and land uses," New Zealand Journal of Agricultural Research, vol. 47, no. 2, pp. 167-177, 2004.

[6] L. A. Gaston, M. A. Locke, R. M. Zablotowicz, and K. N. Reddy, "Spatial variability of soil properties and weed populations in the Mississippi Delta," Soil Science Society of America Journal, vol. 65, no. 2, pp. 449-459, 2001.

[7] C. W. Fraisse, K. A. Sudduth, N. R. Kitchen, and J. J. Fridgen, "Use of unsupervised clustering algorithms for delineating within Colfield management zones," ASAE Paper 993043, ASAE, Ontario, Canada, 1999.

[8] J. C. Davis, Statistics and Data Analysis in Geology, John Wiley \& Sons, New York, NY, USA, 2nd edition, 1986.

[9] A. B. Mcbratney and M. J. Pringle, "Estimating average and proportional variograms of soil properties and their potential use in precision agriculture," Precision Agriculture, vol. 1, no. 2, pp. 125-152, 1999.

[10] P. Goovaerts, Geostatistics for Natural Resources Evaluation, Oxford University Press, New York, NY, USA, 1997.

[11] R. Lal and M. K. Shukla, Principles of Soil Physics, Marcel Dekker, New York, NY, USA, 2004.

[12] J. Iqbal, J. A. Thomasson, J. N. Jenkins, P. R. Owens, and F. D. Whisler, "Spatial variability analysis of soil physical properties of alluvial soils," Soil Science Society of America Journal, vol. 69, no. 4, pp. 1338-1350, 2005.

[13] J. W. Biggar and D. R. Nielsen, "Spatial variability of leaching characteristics of a field soil," Water Resources Research, vol. 12, no. 1, pp. 78-84, 1976.

[14] J. Bouma, "Use of physical methods to expand soil survey interpretations of soil drainage conditions," Soil Science Society of America Proceedings, vol. 37, no. 3, pp. 413-421, 1973. 
[15] J. G. Stockton and A. W. Warrick, "Spatial variability of unsaturated hydraulic conductivity," Soil Science Society of America Proceedings, vol. 35, pp. 847-848, 1971.

[16] J. A. Sobieraj, H. Elsenbeer, and G. Cameron, "Scale dependency in spatial patterns of saturated hydraulic conductivity," Catena, vol. 55, no. 1, pp. 49-77, 2004.

[17] J. L. Smith, J. L. Halvorson, and R. I. Papendick, "Using multiple-variable indicator kriging for evaluating soil quality," Soil Science Society of America Journal, vol. 57, no. 3, pp. 743749, 1993.

[18] SRDI (Soil Resource Development Institute) Staff, Soil Salinity in Bangladesh 2000, Soil Resources Development Institute, Government of the Peoples Republic of Bangladesh, Dhaka, Bangladesh, 2003.

[19] M. R. Rahman, Soils of Bangladesh, Darpon Publications, Dhaka, Bangladesh, 2005.

[20] D. L. Karlen and D. E. Stott, "A framework for evaluating physical and chemical indicators of soil quality," in Defining Soil Quality for a Sustainable Environment, J. W. Doran, D. C. Coleman, D. F. Bezdicek, and B. A. Stewart, Eds., vol. 35 of SSSA Special Publication, pp. 53-72, ASA, CSSA, and SSSA, Madison, Wis, USA, 1994.

[21] P. R. Day, "Particle formation and particle analysis," in Methods of Soil Analysis. Agronomy Monograph, Part 1, C. A. Black, D. D. Evans, J. L. White, L. E. Ensminger, and F. E. Clark, Eds., pp. 545-567, ASA and SSSA, Madison, Wis, USA, 1965.

[22] G. R. Blake and K. H. Hartge, "Bulk density", in Methods of Soil Analysis, A. Klute and A. L. Page, Eds., pp. 363-376, American Society of Agronomy, Madison, Wis, USA, 1986.

[23] E. Strickling, "Relationship of porosity of water stability," Soil Science, vol. 80, pp. 331-335, 1956.

[24] C. M. F. van Bavel, "Mean weight diameter of soil aggregates as a statistical index of aggregation," Soil Science Society of America Proceedings, vol. 14, pp. 20-23, 1949.

[25] A. Klute and C. Dirksen, "Hydraulic conductivity and diffusivity: Laboratory methods," in Methods of Soil Analysis, Part 1, A. Klute and A. L. Page, Eds., pp. 687-732, American Society of Agronomy, Madison, Wis, USA, 2nd edition, 1986.

[26] USDA (United States Department of Agriculture) Staff, Soil Survey Manual, USDA, Washington, DC, USA, 1993.

[27] W. D. Reynolds, X. M. Yang, C. F. Drury, T. Q. Zhang, and C. S. Tan, "Effects of selected conditioners and tillage on the physical quality of a clay loam soil," Canadian Journal of Soil Science, vol. 83, no. 4, pp. 381-393, 2003.

[28] D. G. M. Hall, M. J. Reeve, A. J. Thomasson, and V. F. Wright, "Water retention, porosity and density of field soils," Soil Survey Technical Monograph 9, Rothamsted, Harpenden, UK, 1977.

[29] W. D. Joshua and M. Rahman, "Physical properties of soils in the Ganges river floodplain of Bangladesh," FAO/UNDP Project BGD/81/023, Soil Resource Development Institute (SRDI), Dhaka, Bangladesh, 1983.

[30] D. J. McQueen and T. G. Shepherd, "Physical changes and compaction sensitivity of a fine-textured, poorly drained soil (Typic Endoaquept) under varying durations of cropping, Manawatu region, New Zealand," Soil and Tillage Research, vol. 63, no. 3-4, pp. 93-107, 2002.

[31] S. M. F. Rabbi, K. Q. Kibria, A. Rahman, M. S. Islam, M. R. Bhuiyan, and M. Ahsan, "Aggregate stability of Ganges tidal floodplain soils and its relationship with soil physical and chemical properties," Bangladesh Journal of Soil Science, vol. 30, pp. 61-69, 2004.
[32] C. A. Cambardella, T. B. Moorman, J. M. Novak et al., "Fieldscale variability of soil properties in central Iowa soils," Soil Science Society of America Journal, vol. 58, no. 5, pp. 1501-1511, 1994.

[33] B. F. Ryan and B. L. Joiner, Minitab Handbook, Cengage Learning, Duxbury, Minn, USA, 2001.

[34] A. G. Journel and C. J. Huijbregts, Mining Geostatistics, Academic Press, London, UK, 1978.

[35] E. H. Isaaks and R. M. Srivastava, Applied Geostatistics, Oxford University Press, New York, NY, USA, 1989.

[36] K. Loague and R. E. Green, "Statistical and graphical methods for evaluating solute transport models: overview and application," Journal of Contaminant Hydrology, vol. 7, no. 1-2, pp. 5173, 1991.

[37] SRDI (Soil Resource Development Institute) Staff, Reconnaissance Soil Survey Report of Sadar and Bagerhat Subdivision of Khulna District, Soil Resource Development Institute, Government of the Peoples Republic of Bangladesh, Dhaka, Bangladesh, 1977.

[38] USDA (United States Department of Agriculture) Staff, Soil Quality Kit Guide, USDA-NRCS-ARS-SQI, Washington, DC, USA, 1999.

[39] O. Schabenberger and F. J. Pierce, Contemporary Statistical Models for the Plant and Soil Sciences, CRC Press, Boca Raton, Fla, USA, 2002.

[40] T. Tsegaye and R. L. Hill, "Intensive tillage effects on spatial variability of soil physical properties," Soil Science, vol. 163, no. 2, pp. 143-154, 1998.

[41] M. Basaran, A. U. Ozcan, G. Erpul, and M. R. Canga, "Spatial variability of organic matter and some soil properties of mineral topsoil in Cankiri Indagi Blackpine (Pinus nigra) plantation region," Journal of Applied Sciences, vol. 6, no. 2, pp. 445-452, 2006.

[42] M. K. Shukla, R. Lal, and D. VanLeeuwen, "Spatial variability of aggregate-associated carbon and nitrogen contents in the reclaimed minesoils of Eastern Ohio," Soil Science Society of America Journal, vol. 71, no. 6, pp. 1748-1757, 2007. 

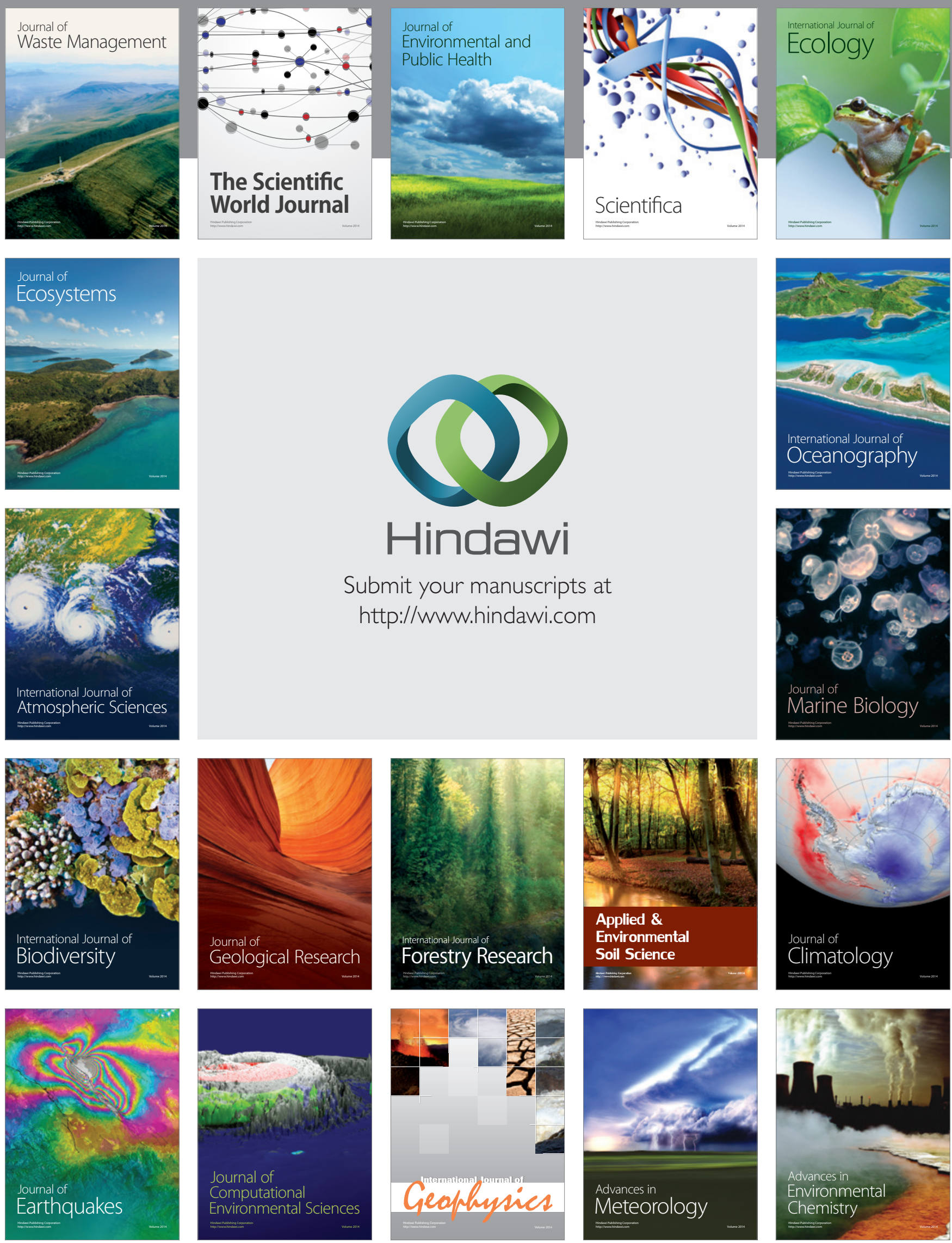